\title{
Fiscal policy and the pandemic
}

\section{Mario Draghi ${ }^{1}$}

Published online: 15 October 2021

○) Springer Nature Switzerland AG 2021

Honourable President of the Republic,

Honourable Presidents of the Senate, of the Chamber of Deputies, of the Constitutional Court,

Honourable Ministers,

Honourable Governor of the Bank of Italy,

Honourable President of the Lincei Academy,

Honourable Emeritus Presidents,

Honourable Fellows,

Distinguished Authorities,

I have many reasons to be grateful to the Lincei Academy today: the prestigious Feltrinelli Prize, the reason for the award, the chance to give this lecture in an institution whose guiding light is research, in a setting made illustrious by the scientific merits of its Fellows.

There are also more personal reasons for my gratitude today. I see the faces of lifelong friends in the audience. I am reminded that those who shaped my economic thinking have all been Fellows of the Lincei Academy:

- Federico Caffè-elected Fellow in 1970

- Sergio Steve-elected Fellow in 1967

- Franco Modigliani-elected Foreign Fellow in 1991, and recipient of the Nobel Memorial Prize in Economics

- Robert Solow-elected Foreign Fellow in 1985, also a Nobel laureate in Economics

Lectio Magistralis delivered by Mario Draghi at the Award Ceremony for the International Feltrinelli Prize (2020) for "Monetary Institutions" at the Accademia Nazionale dei Lincei in Rome, Italy, on 1 July 2021. As Editor in Chief of this Journal, I warmly thank Professor Mario Draghi for permission to publish the English version of the Lectio Magistralis in which he provides an enlightened viewpoint for this crucial period. The Italian version of this Lectio will be published in the "Rendiconti delle Adunanze Solenni" of the Accademia Nazionale dei Lincei, which I also sincerely thank. Alberto Quadrio Curzio.

Mario Draghi

m.draghi@governo.it

$1 \quad$ Presidente del Consiglio della Repubblica Italiana, Rome, Italy 
Today, I thank all of them, and all of you.

It has been slightly more than a year since the outbreak of the health crisis, but we can finally look at the future with more confidence. The vaccination campaign is proceeding well in Italy and Europe. After months of isolation and social distancing, we have resumed, to a large degree, our social interactions. The economy is recovering and schools have re-opened. But we must be realistic. The pandemic is not over. Even when it will be, we will have to deal with its consequences for a long time. One of them is debt-the subject of today's lecture.

The economic crisis that began a year ago is unprecedented in recent history. The recession has been largely caused by conscious decisions taken by governments. In order to prevent the catastrophic spread of the virus, we had to impose restrictions that forced us to shut down many sectors of the economy.

There was no alternative. Protecting our health and protecting the economy were not conflicting objectives. The intense circulation of the virus and the risk that our healthcare system would collapse meant consumption and investment had to be put on hold. Public health had to take precedence.

At that stage, we could only choose between a recession and a depression. We could help the largest possible number of companies overcome the lockdowns and remain on the market, and hence shoulder a severe, but temporary recession. Or we could do nothing, as suggested by those who had not understood the severity of the situation at the start of the pandemic.

In the second case, the sudden and sharp drop in consumption and investment would have led to an array of bankruptcies, triggering a severe depression. It would have led to the shutting down of entire supply chains, with dire consequences not only for the future of our economy, but also for the future of our country.

The cost of choosing a recession over a depression was the surge in debt. This increase over the past months has been deliberate, and most importantly desirable. The pandemic is a natural disaster. Many companies had to stop production, not because of any fault of their own, but because of government restrictions. It was in our best collective interest to keep their productive capacity intact and preserve jobs. The only way to keep these companies in business was to give them enough funds to offset partially the loss of revenue and help them to protect jobs.

We did this through subsidies and bank guarantees. Since the start of the crisis, we have handed out $€ 208$ billion in loan guarantees to companies and roughly $€ 100$ billion in subsidies. Subsidies increased public debt. Bank guarantees increased private debt. The rise in overall debt compared to 2019 is a very clear measure of the economic cost of the pandemic-notwithstanding its dramatic impact on inequalities.

By the end of this year, the debt-to-GDP ratio in the EU will increase by 15 percentage points compared to 2019. According to the European commission forecasts, Italy's public debt will increase from $135 \%$ of GDP to $160 \%$. This increase is higher than during the Great Recession.

In addition, there has also been a considerable increase in private debt. This phase of growing public and private debt is likely not over, for many reasons. We will face the emergence of new and dangerous variants of the virus. And we stand 
ready to intervene with determination, should the pandemic worsen and damage the economy.

It won't be easy to bring people back into the labour market after the damages caused by the crisis. The government will continue to provide support, as it has done over the past two years. The European Central Bank (ECB) has estimated that, without government aid, households in the euro area would have lost on average almost a quarter of their labour income. Thanks to state intervention, the drop was $7 \%$.

Lastly, bank loan guarantees were necessary to let credit institutions provide liquidity to companies in need quickly and at a reasonable rate. Nonetheless, at that stage, it was not possible, neither for governments nor for banks, to distinguish accurately between companies that would be able to survive after the pandemic and those that would not. It was impossible to do so: we did not know how much the health crisis had transformed our habits and our consumption patterns, and we still do not know how much it will transform them. It is inevitable that a portion of this implicit debt will turn into an actual increase in public debt.

Another reason for keeping an expansionary fiscal policy is stimulating growth. The Italian economy has been growing below potential for a large part of the past decade. There is ample room for using expansionary fiscal policy before stoking inflationary pressures. We have already implemented an expansionary fiscal policy over the past 2 years. In 2020 Italy's public deficit was $9.5 \%$ of GDP; this year, according to the European Commission, it should be around $11.7 \%$.

The latest forecasts by the Commission predict an increase in GDP this year of $4.2 \%$ in Italy and the EU. I believe that these estimates will be revised upwards significantly. Consumers and entrepreneurs are regaining confidence. The ECB has stated that it intends to maintain favourable financial conditions. As uncertainty starts to recede, the expansionary effect of monetary policy will gain further momentum. Families and companies are more willing to take out loans and invest when the future looks more favourable.

Nonetheless, the economic recovery alone is not sufficient to repair the damage caused by the pandemic. We must reach higher and more sustained growth rates than in the recent past, to help not only those who were unemployed before the pandemic, but also those who lost their jobs over the past months and those who could lose them in the coming years.

The restrictions imposed during these past months have changed our consumption habits and our production patterns. The digital transformation of European companies last year, especially of smaller ones, has taken place at an accelerated pace-some say even seven times faster-compared to previous years.

That is good news, but we also need to think about those who will face the negative consequences of this transformation. Low-skilled workers are especially vulnerable in this era of digitization. We aim to introduce active labour market policies to allow those who are unemployed to learn the skills that are needed for the jobs of the future.

We must grow at a faster rate also to control the increase of public debt. If we raise the structural growth rate of the economy above what it was before the health crisis, we will be able to increase tax revenues enough to balance out the debt generated during the pandemic. In turn, that will create additional demand, reducing the 
risk of companies defaulting and hence lowering the actual cost of government loan guarantees.

These objectives are not only desirable, but also achievable. As I have already stated, the debt-to-GDP ratio in Europe and in Italy has increased by 20 percentage points over the past 2 years.

Even if we use an interest rate that is cautiously high (around 2.5\%), the annual cost of servicing debt will amount to half a percentage point of our national income. Since government revenues in Italy and in Europe amount to around 40-50\% of GDP, increasing the structural growth rate by $1-1.25$ percentage points will be enough to cover the cost of the debt generated over the past 2 years.

However, not all expansionary fiscal policies are the same. We must focus especially on investment since it stimulates demand and improves supply. Our government has done so when it presented its National Recovery and Resilience Plan, approved by the European Commission last week. The investment strategy foreseen in the Plan is needed to overcome the physical and digital infrastructure gaps that have accumulated over the past decades.

This is why Italy has decided to make full use of the funds-subsidies and loans - made available by the European Union.

At the same time, we must overcome many structural barriers that prevent us from reaching our full potential and relaunching productivity. In 2019, Italy's total factor productivity, which measures the economy's overall efficiency, was lower than in 2001.

Implementing our reform agenda means increasing productivity.

We have already simplified administrative procedures. We have launched a reform of the public administration and of public sector hiring. We have overhauled the Ministry for the Environment, granting it new and important powers, and transformed it into the Ministry for Ecological Transition. We have created the Ministry of Technological Innovation and Digital Transition. The next steps include reforming the civil justice system and competition rules, and simplifying public procurement. We want to rebuild trust between the state and entrepreneurs and encourage the private sector to invest in Italy more than it has done over the last few years.

Lastly, we must increase the participation of young people and women in the labour market. While it is true that there can be no social cohesion without growth, it is also true that there can be no growth without social cohesion. Young people are the most vulnerable to the fragilities of our economy. In Southern Italy, one out of three does not study or is unemployed. That is why it is important to favour the transition from school to work. We need to provide schools with programmes that allow students to invest early on in specific skills that match their talents and aspirations. We need to upgrade technical and professional institutes and strengthen their ties with the labour market so that the supply of skilled human capital can quickly match the needs of companies. Furthermore, we need to improve the teaching of so-called STEM subjects (science, technology, engineering, mathematics), to encourage more young people to choose careers in science.

Women often have to shoulder the largest share of caregiving activities within the family. We saw this during the most acute phase of the pandemic, when they suffered the consequences of the restrictions to a greater degree than men. We must address 
the lack of childcare and elderly care facilities. Not only will this help women who need to enter the labour market, but it will also help those who are already working to advance their careers.

Today, it is good to increase government debt, but this is not always the case. This brings me to a distinction that I mentioned a few months ago, between what I call 'good debt' and 'bad debt'. What makes debt good or bad is the use of the resources. The distinction is particularly important during a transition phase, as the one we live in, when the difference in productivity of prospective investments can be greater. Debt can strengthen us if it improves the wellbeing of our country, as was the case during the pandemic. It can weaken us, as has all too often occurred in the past, if the resources are wasted. It can unite us if it helps Italy and Europe reach the goal of sustainable prosperity. However, debt can divide us if it raises the spectre of moral hazard and budget transfers, as after the financial crisis.

Consider, for example, the joint debt that is financing Next Generation EU. Our country is the main beneficiary of this programme; therefore, it has an enormous responsibility toward ensuring its success. If we use these resources productively and with honesty, not only will we help the Italian economy, but we will also boost trust within the EU, and provide a significant contribution to the process of European integration.

More generally, public debt that qualifies as good debt is:

- debt that finances well-targeted public investment projects

- debt that helps to absorb exogenous shocks, such as a war or, indeed, a pandemic

- debt used for countercyclical policies.

Countercyclical fiscal policy is particularly important in a monetary union, since monetary policy cannot respond on its own to isolated shocks that affect a single country.

It is even more so today, given how close interest rates are to their lower bound, thereby reducing the ability of the ECB to support aggregate demand. Nonetheless, not all countries in the euro area are equally able to use fiscal policy as a stabilising mechanism. Sovereign debt that is considered unsafe can only partially serve this purpose, since it can lead to higher interest rates. Only a few countries have sovereign debt that is considered risk-free by the market. These countries can issue all the necessary debt to contrast a slump in private demand during a crisis without triggering an increase in interest rates.

An example is what occurred during the 2011 crisis. The public debt of certain countries, such as Italy, was not considered safe by investors exactly when governments needed to issue debt to respond to the crisis. The fiscal space of these countries was curtailed when they most needed it because their interest rates had increased.

In recent years, the ECB has countered the problem with an expansionary monetary policy, justified by the fact that the inflation rate over the medium term has remained much lower than the ECB's target. This stopped economies from falling into a vicious cycle, such as the one in 2011, when the lack of trust in sovereign debt generated an increase in interest rates, forcing governments to implement 
contractionary policies in an attempt to gain credibility. Their economic growth was affected while their credibility continued to decrease and interest rates continued to rise. Today, the inflation rate inside the euro area remains low and requires an accommodative monetary policy. Nonetheless, these circumstances may not reoccur in the future, if inflationary expectations were to go above the ECB's statutory objectives for a prolonged time.

We must reflect, at the EU level, on how to allow member states to issue safe debt in times of recession to stabilize their economies. The discussion on reforming the Stability Pact, which has been suspended until the end of 2022, offers an ideal opportunity to do so. A credible solution to the problem would improve the euro area's capacity to handle a crisis and at the same time further strengthen the ECB's independence. An expansionary fiscal policy is not in contrast with a gradual decrease of the debt-to-GDP ratio that is needed in the medium term to reduce the vulnerability that comes with excessive debt.

We must, however, lift our gaze from the horizon of macroeconomics to reflect on the profound changes our societies are going through. The energy transition, the awareness of the importance of research and the process that will lead future generations toward the 2030 and 2050 objectives, grant governments a crucial active role. This is true for building key R\&D infrastructure, and for encouraging private investment in priority areas, creating confidence, simplifying administrative procedures, helping companies to manage risk in new fields, developing shared and transparent decarbonization policies.

This is a favourable time for Italy. The confidence provided by Europe and by government decisions, the ability to overcome partisan barriers, and the abundance of public and private financial capital are exceptional circumstances for companies and families that will invest their capital and savings in technology, education and modernisation. It is also a favourable time for combining efficiency and fairness, growth and sustainability, technology and employment. It is a time when we want to look at the future with greater confidence.

Let's live it fully, with determination and solidarity.

Publisher's Note Springer Nature remains neutral with regard to jurisdictional claims in published maps and institutional affiliations. 